\title{
Keefektifan Insektisida BPMC dan Ekstrak Daun Suren terhadap Hama Wereng Batang Coklat (Nilaparvata lugens Stal.) dan Populasi Musuh Alami pada Padi Varietas Ciherang
}

\author{
Muhammad Subandi, Liberty Chaidir dan Ulfah Nurjanah \\ Jurusan Agroteknologi, Fakultas Sains dan Teknologi UIN Bandung \\ Jl. AH Nasution No. 105, Bandung, Jawa Barat 40614 \\ *Alamat korespondensi: mhd.subandi@uinsgd.ac.id
}

\begin{abstract}
Effectiveness of BPMC insecticide and suren leaf extract on brown planthopper (Nilaparvata lugens Stal.) and its natural enemy population on Ciherang rice variety
\end{abstract}

Effectiveness study of BPMC insecticide and suren leaf extract esticide against brown planthopper and its side-effect on its natural enemy population on paddy Ciherang variety was conducted in rice field of Balai Besar Peramalan Organisme Pengganggu Tumbuhan (BBPOPT), Karawang, West Java from May to August 2015. The experimental design used was Randomized Blok Design with 7 treatments and 4 replications ie suren leaf extract of $50 \mathrm{~g} / \mathrm{l}, 100 \mathrm{~g} / \mathrm{l}$ and $150 \mathrm{~g} / \mathrm{l}$, three concentrations of BPMC of $0.5 \mathrm{ml} / 1,1.0 \mathrm{ml} / 1$ and $1.5 \mathrm{ml} / \mathrm{l}$, and a control treatment. The results showed that BPMC insecticide and suren leaf extract were able to suppress the population of brown planthopper and influenced its natural enemy population. The treatment of $50 \mathrm{~g} / 1$ suren leaf extract gave the highest suppression of the brown planthopper population. It was also caused no negative impact to the natural enemies of $P$. fuscipes and $L$. pseudoannulata. The application of 1.5 $\mathrm{ml} / 1$ of BPMC insecticide gave the highest grain weight average of $37.80 \mathrm{~kg} / \mathrm{plot}$ compared to the lowest production in control treatment of $32.63 \mathrm{~kg} / \mathrm{plot}$. Therefore, application of BPMC insecticide and suren leaf extract effectively suppressed the brown planthopper population and the natural enemy existence was assumed to affect the rice grain production in this study.

Keywords: BPMC insecticide, Natural enemy, Suren, Planthopper

\begin{abstract}
ABSTRAK
Studi keefektifan insektisida BPMC dan ekstrak daun suren terhadap hama wereng batang coklat (WBC) dan efek samping terhadap musuh alami wereng pada padi varietas Ciherang dilaksanakan di sawah Balai Besar Peramalan Organisme Pengganggu Tumbuhan (BBPOPT) Karawang mulai Mei 2015 sampai Agustus 2015. Rancangan yang digunakan Rancangan Acak Kelompok (RAK) dengan 7 perlakuan dan 4 ulangan yaitu perlakuan tanpa insektisida (kontrol), 50 g/l ekstrak daun suren, $100 \mathrm{~g} / \mathrm{l}$ ekstrak daun suren, $150 \mathrm{~g} / \mathrm{l}$ ekstrak daun suren, $0,5 \mathrm{ml} / \mathrm{l}$ insektisida BPMC, 1,0 ml/1 insektisida BPMC, dan 1,5 ml/l insektisida BPMC. Hasil menunjukkan perlakuan insektisida BPMC dan ekstrak daun suren dapat menekan populasi hama WBC dan memengaruhi populasi musuh alaminya (Paederus fuscipes dan Lycosa pseudoannulata). Perlakuan ekstrak daun suren konsentrasi $50 \mathrm{~g} / 1$ dapat menekan populasi WBC tertinggi. Aplikasi ekstrak daun suren tidak berdampak negatif terhadap musuh alami $P$. fuscipes dan L. pseudoannulata. Perlakuan $1,5 \mathrm{ml} / 1$ insektisida BPMC menghasilkan produksi gabah tertinggi dari semua perlakuan dengan rata-rata bobot basah gabah 37,80 kg/petak dibandingkan dengan hasil terendah pada perlakuan kontrol sebesar 32,63 kg/petak. Dengan demikian, aplikasi insektisida BPMC dan ekstrak daun suren berpengaruh terhadap populasi hama WBC dan efek samping dari tingkat keberadaan musuh alami berakibat pada hasil gabah tanaman padi.
\end{abstract}

Kata Kunci: Insektisida BPMC, Musuh alami, Suren, Wereng 


\section{PENDAHULUAN}

Wereng batang coklat (WBC), Nilaparvata lugens Stal., merupakan hama utama tanaman padi yang dapat menyebabkan kerusakan tanaman dalam waktu relatif singkat. Kerusakan pada tanaman padi disebabkan oleh kegiatan makan hama WBC dengan menghisap cairan sel tanaman sehingga tanaman menjadi layu, mongering dan akhirnya Nampak seperti terbakar (hopperburn) (Sutrisno, 2014). Ledakan hama telah sering dilaporkan karena populasi WBC yang tinggi di beberapa tempat penanaman padi. Berbagai metode telah dilakukan petani untuk mengendalikan hama WBC pada padi baik secara biologi, fisik dan mekanik (Sjakoer, 2010). Namun demikian, pengendalian secara biologi ini dianggap kurang efektif dan penggunaan pestisida sintetik masih dianggap cara pengendalian yang lebih praktis dan cepat (Caraycaray, 2004).

Insektisida BPMC adalah insektisida kimia yang berbahan aktif buthylphenylmethyl carbamate $500 \mathrm{~g} / \mathrm{l}$. Insektisida BPMC mempunyai daya basmi tinggi dan mempunyai knock down efek yang cepat. Keefektifan insektisida BPMC terhadap WBC telah dilaporkan (Nagata, 1985). Insektisida BPMC mempunyai cara kerja menghambat enzim kolinesterase dalam tubuh, tetapi reaksi yang ditimbulkannya bersifat reversible (dapat balik) dan bekerja lebih banyak pada jaringan, bukan dalam plasma darah. BPMC bekerja mengikat asetilkolinesterase. Asetilkolinesterase adalah enzim yang diperlukan untuk menjamin kelangsungan vertebrata dan insekta. Fungsi asetikolinesterase adalah mengatur produksi dan degradasi asetilkolin, suatu neurotransmiter pada sistem saraf otomom (parasimpatik) dan somatik (Wispriyono dkk., 2013). Namun demikian, disamping berpengaruh positif dalam menekan hama wereng, aplikasi pestisida juga diperkirakan berpengaruh pada populasi musuh alami hama wereng. Dua organisme musuh alami wereng yang utama adalah tomcat (Paederus fuscipes) dan laba-laba (Lycosa pseudoannulata/wolf spider). Rizkie dkk. (2015) menyebutkan bahwa penggunaan insektisida sintetik yang berlebihan dan tidak tepat tidak akan mengatasi hama dengan benar tetapi sebaliknya dapat menimbulkan berbagai dampak negatif seperti pencemaran lingkungan, resistensi hama sasaran dan menimbulkan terjadinya resurgensi hama. IRAC (2012) menyebutkan ada bukti kelompok WBC yang memperlihatkan keadaan resisten terhadap satu atau beberapa pestisida termasuk golongan karbamat.
Sutrisno (2014) menyebutkan bahwa resistensi WBC terhadap insektisida merupakan salah satu faktor yang berkontribusi dalam letusan hama WBC karena insektisida yang digunakan kurang efektif atau tidak efektif lagi.

Sementara itu, komponen pengendalian lain selain penggunaan insektisida kimia seperti pengendalian secara biologis dengan memanfaatkan musuh alami dan penggunaan insektisida nabati dipercaya merupakan pengendalian yang aman dan mampu menjaga keseimbangan ekosistem, serta dapat menghindari kejadian resistensi hama sasaran (Syahrawati dkk., 2010). Luo et al. (2014) menjelaskan bahwa tanaman, gulma, hama dan musuh alami hama adalah bagian penting dari ekosistem tanaman padi dimana pengelolaan komponen-komponen tersebut akan menjamin budidaya padi yang berkelanjutan. Musuh alami hama akan berperan dalam menurunkan populasi hama sampai pada tingkat populasi yang tidak merugikan (Santosa \& Sulistyo, 2007). Musuh alami yang dapat mengendalikan WBC adalah parasitoid, predator dan patogen dimana kumbang tomcat merupakan salah satu predator utama hama tanaman padi (Hadi, 2012).

Di dalam penelitian ini, insektisida nabati yang dibandingkan penggunaan dengan insektisida kimia BPMC adalah ekstrak daun suren. Suren dilaporkan memiliki kandungan senyawa triterpenoid diantaranya yaitu surenon, surenin dan surenolakton (Hidayati dkk., 2013). Senyawa tersebut bersifat sebagai insektisida yang dapat membunuh serangga sasaran dengan cara masuk ke pencernaan melalui makanan yang mereka makan. Triterpenoid ini akan diserap oleh saluran pencernaan tengah yang berfungsi sebagai tempat penghancuran makanan secara enzimatis.

\section{BAHAN DAN METODE}

Penelitian dilakukan di sawah Balai Besar Peramalan Organisme Pengganggu Tumbuhan (BBPOPT) Karawang dari bulan Mei sampai bulan Agustus 2015 dengan menggunakan padi varietas Ciherang. Metode pengujian menggunakan metode eksperimen dengan Rancangan Acak Kelompok (RAK) terdiri atas 7 perlakuan yaitu 3 perlakuan ekstrak daun suren dengan konsentrasi 50 g/l, 100 $\mathrm{g} / \mathrm{l}$, dan $150 \mathrm{~g} / \mathrm{l}$, serta 3 perlakuan insektisida BPMC konsentrasi $0,5 \mathrm{ml} / 1,1,0 \mathrm{ml} / 1$ dan $1,5 \mathrm{ml} / \mathrm{l}$, dan perlakuan kontrol yang masing-masing diulang 4 kali. Aplikasi insektisida BPMC dan ekstrak daun 
suren dilakukan setiap 2 minggu sekali yaitu pada saat umur padi 21 hari setelah tanam (HST), 35 HST dan 49 HST dengan menggunakan knapsack sprayer. Rancangan respons terdiri atas populasi WBC (ekor), populasi musuh alami tomcat dan laba-laba (ekor), dan bobot gabah per petak $(\mathrm{kg})$. Analisis beda nyata diuji lanjut dengan menggunakan metode uji Duncan dan uji Dunnett. Tingkat efikasi insektisida dihitung dengan formula Abbot (1925) dalam Baehaki dkk. (2011) sebagai berikut:

$$
\mathrm{IE}=\{(\mathrm{Ca}-\mathrm{Ta}) / \mathrm{Ca}\} \times 100 \%
$$

$\mathrm{IE}=$ Efikasi insektisida yang diuji (\%)

$\mathrm{Ta}=$ Populasi wereng coklat pada pot perlakuan insektisida yang diuji setelah penyemprotan insektisida

$\mathrm{Ca}=$ Populasi wereng coklat pada pot kontrol setelah penyemprotan insektisida

Ekstrak daun suren disiapkan dengan cara memotong kecil daun suren yang sudah dijemur selama \pm 2 hari yang kemudian dilender hingga menjadi tepung dan disaring. Tepung daun suren yang sudah disaring dan halus kemudian diblender dengan menambahkan air 1 liter dan alkohol 70\% sebanyak $10 \mathrm{ml}$. Hasilnya dituangkan kedalam wadah dan disimpan selama 1 hari (24 jam). Ekstrak tersebut disaring dan larutannya digunakan sebagai bahan uji insektisida nabati. Detergen $1 \mathrm{~g}$ ditambahkan di dalam aplikasi ekstrak daun suren.

\section{HASIL DAN PEMBAHASAN}

\section{Populasi Wereng Batang Coklat}

Pengamatan awal dilakukan pada saat padi berumur $14 \mathrm{HST}$, namun pada umur $14 \mathrm{HST}$ tidak ditemukan populasi WBC sehingga tidak dilakukan aplikasi insektisida. Pada saat padi berumur 21 HST terdapat populasi WBC sehingga pengaplikasian insektisida dilakukan. Pengamatan populasi WBC ini dilakukan pada padi berumur 21 HST, 35 HST dan 49 HST. Pengamatan dilakukan sebelum dan setelah aplikasi insektisida. Hasil pengamatan lapangan rata-rata populasi WBC dapat dilihat pada Gambar 1.

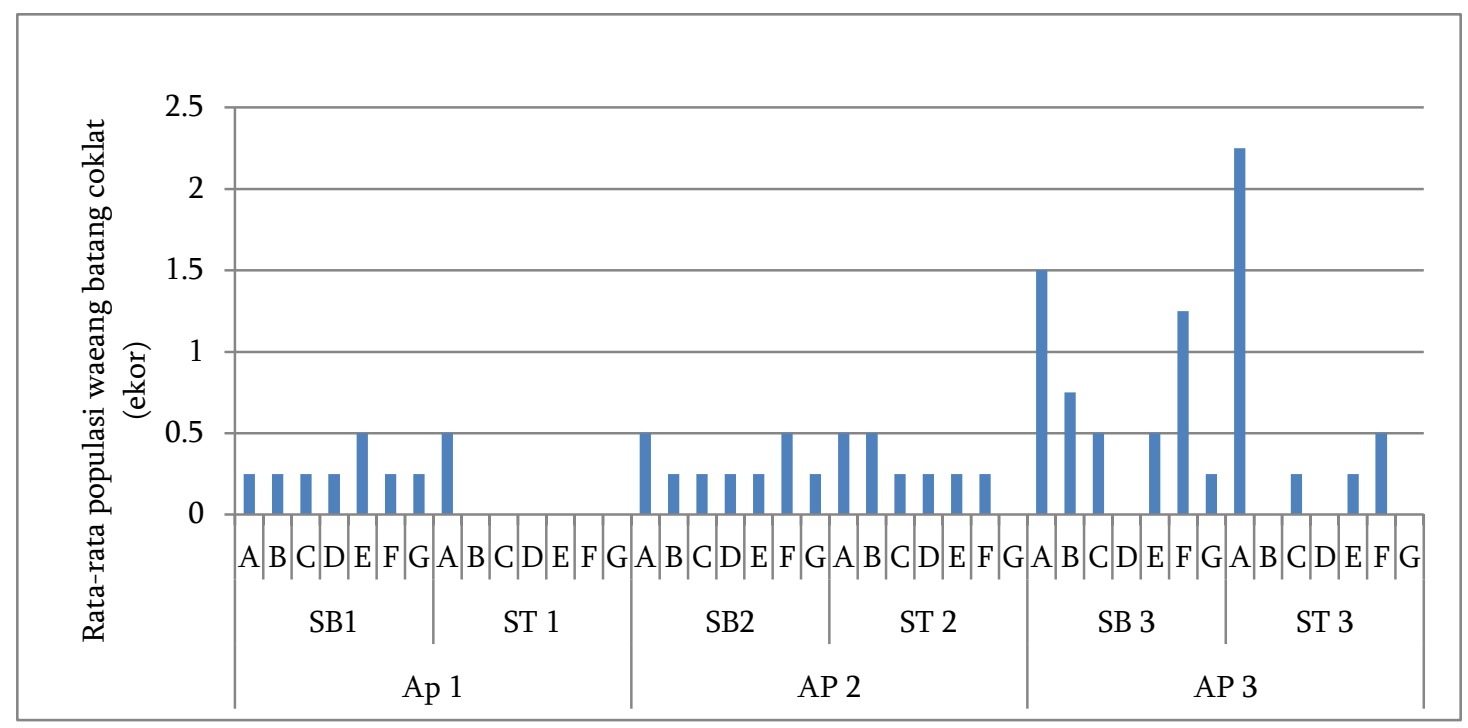

Gambar 1. Rata-rata populasi wereng batang coklat. $\mathrm{A}=$ kontrol (tanpa insektisida), $\mathrm{B}=$ ekstrak daun suren $50 \mathrm{~g} / \mathrm{l}, \mathrm{C}=$ ekstrak daun suren $100 \mathrm{~g} / \mathrm{l}, \mathrm{D}=$ ekstrak daun suren $150 \mathrm{~g} / \mathrm{l}, \mathrm{E}=$ insektisida BPMC 0,5 $\mathrm{ml} / \mathrm{l}, \mathrm{F}=$ insektisida BPMC 1,0 ml/l, G = insektisida BPMC 1,5 ml/l. SB = sebelum aplikasi, $\mathrm{ST}=$ setelah aplikasi. Ap 1 = aplikasi pertama, AP 2= aplikasi kedua, dan AP 3 = aplikasi ketiga.

Dari semua perlakuan setelah aplikasi ketiga menunjukkan bahwa pada petak kontrol setiap minggunya populasi WBC terus bertambah. Akan tetapi pada perlakuan ekstrak daun suren $50 \mathrm{~g} / \mathrm{l}$ setelah aplikasi ketiga populasi WBC tidak ditemukan. Hal itu menunjukkan ekstrak daun suren $50 \mathrm{~g} / \mathrm{l}$ dapat menekan populasi WBC. Pada perlakuan ekstrak daun suren $100 \mathrm{~g} / 1$ setelah aplikasi ketiga ditemukan rata-rata populasi WBC 0,25 ekor per petak, sedangkan pada perlakuan ekstrak daun 
suren $150 \mathrm{~g} / \mathrm{l}$ setelah aplikasi ketiga populasi WBC tidak ditemukan. Dengan demikian, pestisida nabati ekstrak daun suren cukup selektif dan efekif dalam menekan populasi WBC. Sementara itu, hasil pada perlakuan insektisida BPMC $1,5 \mathrm{ml} / 1$ setelah aplikasi ketiga populasi WBC dengan perlakuan BPMC 1,5 $\mathrm{ml} / 1$ tidak ditemukan.

Berdasarkan pengamatan terakhir yaitu pada umur 49 HST atau setelah aplikasi ke-3 menyebabkan rata-rata populasi WBC menurun bahkan tidak ditemukan pada perlakuan ekstrak daun suren $50 \mathrm{~g} / \mathrm{l}, 100 \mathrm{~g} / \mathrm{l}$ dan BPMC 1,5 ml/l. Hal ini menunjukkan insektisida BPMC mampu menekan populasi WBC. Pertambahan dan pengurangan populasi dapat diakibatkan oleh perpindahan WBC, karena pada saat pengamatan WBC yang ditemukan adalah makroptera (wereng yang sudah bersayap). WBC makroptera mempunyai kemampuan untuk terbang sehingga dapat bermigrasi cukup jauh (Nurbaeti dkk., 2010).
Menurut BBPOPT-Dirjen PTP (1992) perkembangan wereng coklat pada pertanaman padi dapat terbagi menjadi 4 (empat) generasi yaitu generasi $0(\mathrm{G} 0)=$ umur padi $0-30 \mathrm{HST}$; generasi 1 (G1) = umur padi 31-60 HST, wereng batang coklat akan menjadi imago wereng batang coklat generasi ke-1; generasi 2 (G2) = umur padi 61-90 HST, wereng batang coklat akan menjadi imago wereng batang coklat generasi ke-2; dan generasi 3 (G3) = umur padi di atas $90 \mathrm{HST}$. Pengendalian wereng yang baik yaitu pada saat generasi nol (G0) dan generasi 1 (G1). Pengendalian wereng harus selesai pada generasi ke-1 (G1). Pengendalian saat generasi ke-2 (G2) atau puso tidak akan berhasil sehingga dilakukan pengaplikasian pada umur 21 HST, 35 HST, dan 49 HST. Oleh karena itu, pada pengendalian generasi 1 diharapkan mampu menekan populasi WBC agar tetap berada di bawah ambang batas ekonomi.

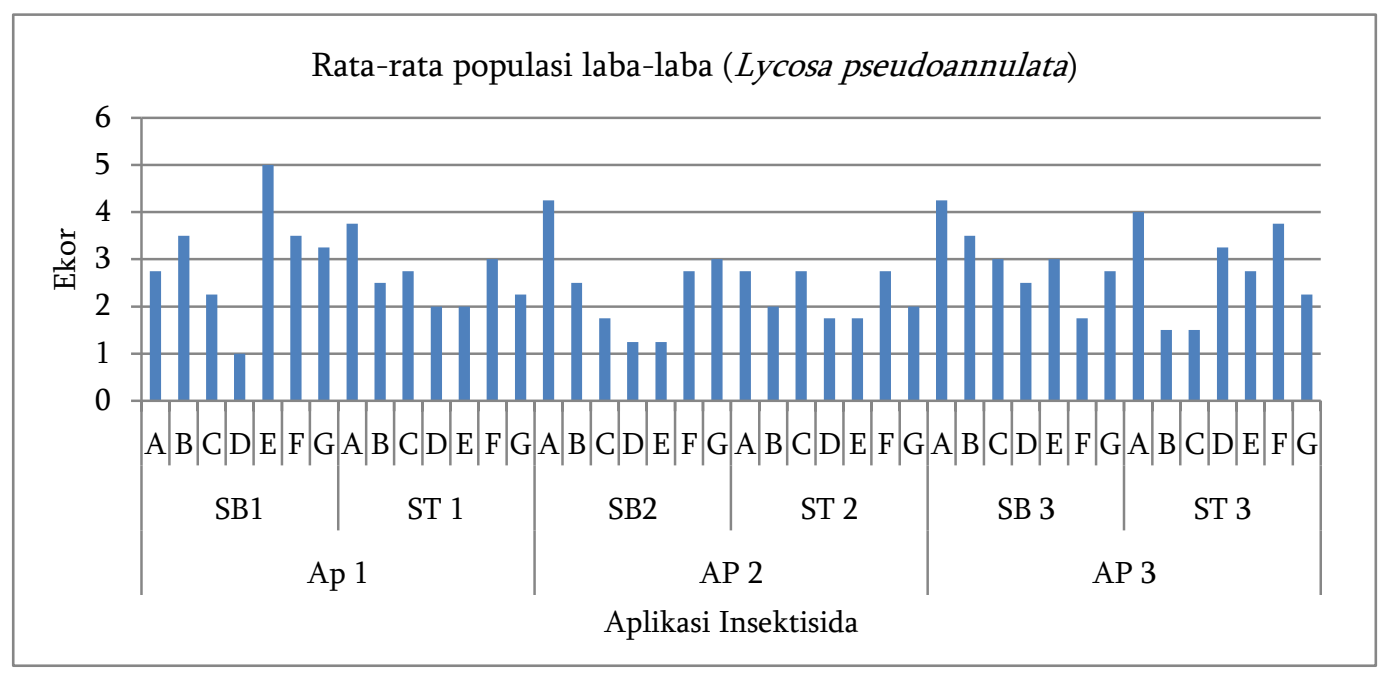

Gambar 2. Rata-rata populasi predator laba-laba (L. pseudoannulata) per petak. A = kontrol (tanpa insektisida), $\mathrm{B}=$ ekstrak daun suren $50 \mathrm{~g} / \mathrm{l}, \mathrm{C}=$ ekstrak daun suren $100 \mathrm{~g} / \mathrm{l}, \mathrm{D}=$ ekstrak daun suren $150 \mathrm{~g} / \mathrm{l}, \mathrm{E}=$ insektisida BPMC 0,5 ml/l, F = insektisida BPMC 1,0 ml/l, G = insektisida BPMC 1,5 ml/l. SB = sebelum aplikasi, $\mathrm{ST}=$ setelah aplikasi. Ap $1=$ aplikasi pertama, AP 2= aplikasi kedua, dan AP $3=$ aplikasi ketiga.

\section{Populasi Musuh Alami}

Aplikasi insektisida BPMC berpengaruh pada kehidupan musuh alami hama WBC pada konsentrasi 1,5 ml/l (Gambar 2). Namun demikian, populasinya diperkirakan masih dapat membantu menekan perkembangan hama WBC. Populasi predator laba-laba (L. pseudoannulata) pada semua perlakuan sebelum dan setelah aplikasi sangat berfluktuasi. Terjadinya fluktuasi pada rata-rata populasi laba-laba tersebut disebabkan oleh labalaba yang sebelum aplikasi muncul namun adanya perlakuan atau kondisi lingkungan (suhu dan kelembaban) menjadi bersembunyi dan begitu juga sebaliknya. Terjadinya penambahan dan pengurangan populasi laba-laba dikarenakan labalaba aktif bergerak sehingga saat aplikasi laba-laba bersembunyi pada dedaunan dan pangkal batang padi atau ada yang non-aktif (mati). 
Berdasarkan hasil pengamatan rata-rata populasi kumbang tomcat (Paederus fuscipes) dapat dilihat pada Gambar 3. Kumbang $P$. fuscipes mempunyai sayap yang menutupi setengah atau kurang dari bagian abdomennya. Ujung perut, kepala dan sayapnya berwarna biru mengkilap sedangkan bagian lainnya berwarna merah dengan ruas-ruas tubuh yang bergaris-garis. Tempat hidupnya di tanaman, air dan tanah dengan rentang hidup 90-110 hari (BBPOPT-Dirjen PTP, 1992).

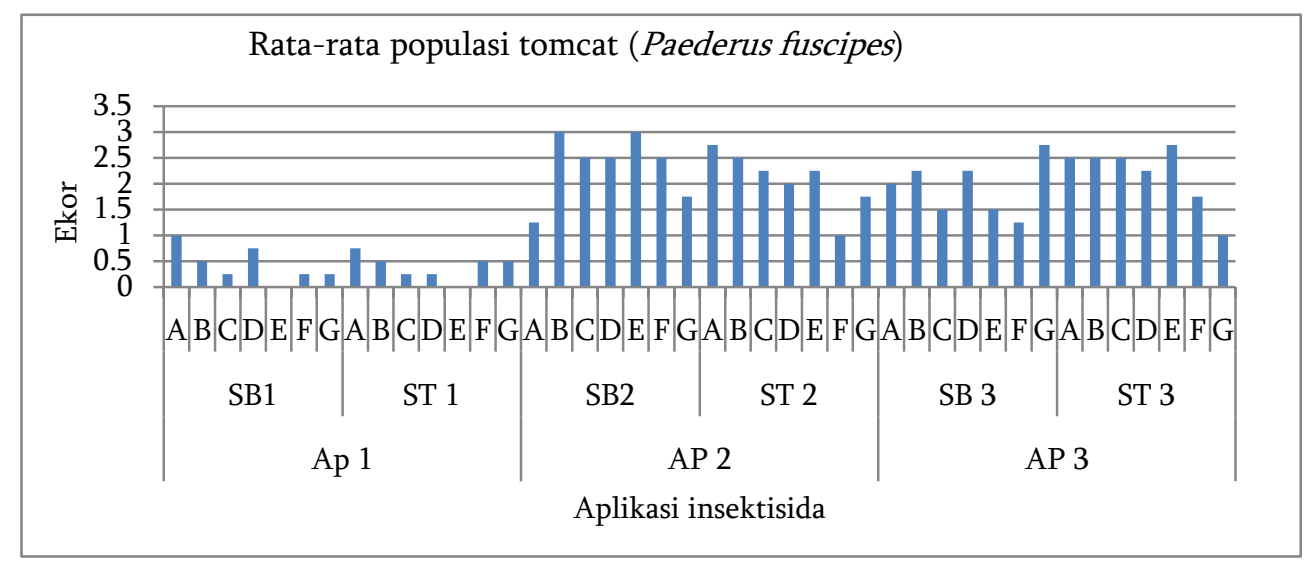

Gambar 3. Rata-rata populasi tomcat ( $P$. fuscipes) per petak. $\mathrm{A}=$ kontrol (tanpa insektisida), $\mathrm{B}=$ ekstrak daun suren $50 \mathrm{~g} / \mathrm{l}, \mathrm{C}=$ ekstrak daun suren $100 \mathrm{~g} / \mathrm{l}, \mathrm{D}=$ ekstrak daun suren $150 \mathrm{~g} / \mathrm{l}, \mathrm{E}=$ insektisida BPMC 0,5 ml/l, F = insektisida BPMC 1,0 ml/l, G = insektisida BPMC 1,5 ml/l. SB = sebelum aplikasi, $\mathrm{ST}=$ setelah aplikasi.

Kumbang $P$. fuscipes mencari mangsa pada malam hari dan lebih banyak memangsa pada stadia awal karena wereng pada stadia awal ukurannya lebih kecil dan belum aktif bergerak sehingga lebih mudah dimangsa. Kemampuan memangsa $P$. fuscipes adalah rata-rata $4,9 \mathrm{WBC}$ per hari. Siklus hidup $P$. fuscipes ini 20,9 hari dan lama hidup serangga dewasanya 80,53 hari sedangkan siklus hidup WBC 30 hari sehingga berdasarkan kemampuan memangsa, siklus hidup, laju pertumbuhan, populasi dan umur serangga dewasa, $P$. fuscipes dapat menurunkan populasi WBC (Santosa \& Sulistyo, 2007). Pada umur padi 21 HST belum banyak ditemukan populasi $P$. fuscipes, namun setelah padi berumur 35 HST sudah mulai banyak ditemukan $P$. fuscipes dan berfluktuasi. Fluktuasi populasi $P$. fuscipes dikarenakan berbagai faktor lingkungan yang memengaruhi tempat hidupnya dan pengaruh insektisida BPMC serta ekstrak daun suren. Pada Gambar 3 dapat dilihat bahwa setelah aplikasi ekstrak daun suren ketiga menunjukkan tidak memengaruhi populasi tomcat tetapi perlakuan insektisida BPMC konsentrasi 1,5 $\mathrm{ml} / \mathrm{l}$ setelah aplikasi ketiga memberikan efek penekanan yang kuat pada populasi tomcat. Namun demikian, insektisida berbahan aktif BPMC yang diaplikasikan pada dosis rendah dan penggunaan yang bijaksana dipercaya tidak berpengaruh buruk terhadap musuh alami. Populasi $P$. fuscipes meningkat pesat pada akhir musim hujan (Maret dan April), kemudian dengan cepat berkurang seiring munculnya cuaca kering pada bulan-bulan berikutnya (Hadi, 2012). Kelembaban udara pada saat penelitian berfluktuasi dengan curah hujan yang terjadi sehingga reproduksi $P$. fuscipes tidak bergantung bulan tetapi bergantung pada kondisi cuaca atau iklim mikro yang terjadi.

\section{Bobot Gabah (Basah) Per Petak}

Perhitungan bobot gabah per petak dilakukan pada saat padi dipanen yaitu pada umur padi 95 HST setelah padi dipanen (dirontokkan) (Tabel 1). Pengamatan dilakukan dengan cara menimbang gabah yang belum dibersihkan dari kotoran dan belum dikeringkan. Bobot gabah yang baru panen biasanya mempunyai kadar air 21\%$25 \%$. Perhitungan bobot ini dapat dijadikan parameter hasil produksi padi dari perlakuan insektisida BPMC dan ekstrak daun suren terhadap WBC. Hasil analisis sidik ragam perbandingan antara insektisida BPMC dengan ekstrak daun suren berbeda nyata. Hasil rata-rata bobot gabah berdasarkan analisis sidik ragam perlakuan ekstrak daun suren $50 \mathrm{~g} / \mathrm{l}$ lebih efektif dibandingkan dengan perlakuan ekstrak daun suren $150 \mathrm{~g} / 1$ dan $100 \mathrm{~g} / \mathrm{l}$. Hal ini dikarenakan perlakuan ekstrak daun suren 
$50 \mathrm{~g} / \mathrm{l}$ mampu menghasilkan bobot gabah tidak jauh berbeda dengan perlakuan lainnya, selain itu lebih efisien terhadap penggunaan bahan baku dan lebih ramah lingkungan daripada perlakuan insektisida BPMC. Pembuatan ekstrak daun suren $50 \mathrm{~g} / \mathrm{l}$ membutuhkan bahan yang sedikit sedangkan pembuatan ekstrak daun suren $100 \mathrm{~g} / 1$ dan $150 \mathrm{~g} / \mathrm{l}$ membutuhkan banyak bahan segar sehingga kurang efektif dalam pelaksanaannya. Selain itu, perlakuan ekstrak daun suren dengan konsentrasi yang tinggi dapat menyebabkan efek fitotoksik pada tanaman dengan menyebabkan daun tanaman menjadi bintikbintik berwarna coklat kehitaman (Noviana, 2011).

Tabel 1. Bobot gabah hasil panen padi varitas Ciherang pada aplikasi insektisida BPMC dan ekstrak daun suren.

\begin{tabular}{lc}
\hline \multicolumn{1}{c}{ Perlakuan } & $\begin{array}{c}\text { Rata-rata bobot } \\
\text { gabah }(\mathrm{kg} / \text { petak })\end{array}$ \\
\hline Kontrol (tanpa insektisida) & $32,63 \mathrm{a}$ \\
Ekstrak daun suren $50 \mathrm{~g} / 1$ & $36,23 \mathrm{bc}$ \\
Ekstrak daun suren $100 \mathrm{~g} / 1$ & $35,33 \mathrm{~b}$ \\
Ekstrak daun suren $150 \mathrm{~g} / 1$ & $36,80 \mathrm{bc}$ \\
Insektisida BPMC 0,5 ml/1 & $36,88 \mathrm{bc}$ \\
Insektisida BPMC 1,0 ml/1 & $36,43 \mathrm{bc}$ \\
Insektisida BPMC 1,5 ml/1 & $37,80 \mathrm{c}$ \\
\hline Keterangan: Angka-angka yang diikuti huruf yang sama \\
menunjukkan berbeda tidak nyata menurut uji \\
Duncan pada taraf nyata 5\%.
\end{tabular}

Bobot gabah tertinggi diperoleh pada perlakuan insektisida BPMC 1,5 ml/l dengan bobot $37,80 \mathrm{~kg} /$ petak yang terendah pada perlakuan kontrol yaitu 32,63 kg. Perlakuan ekstrak daun suren $50 \mathrm{~g} / \mathrm{l}$ menghasilkan bobot basah 36,23 $\mathrm{kg}$ /petak. Fluktuasi bobot (basah) gabah ini berarti terdapat adanya pengaruh akibat perlakuan. Pada saat pengamatan awal, sebelum aplikasi insektisida pertama rata-rata populasi wereng batang coklat dan hama lain sudah ditemukan pada petak kontrol dan hingga pada saat padi berumur 49 HST semakin bertambah sehingga pada petak kontrol WBC dapat berkembang dan menghisap cairan yang ada di batang yang menyebabkan batang padi menjadi kering, jika batang kering maka tidak dapat memproduksi jumlah anakan produktif sehingga malai yang dihasilkan sedikit. Oleh karena itu, bobot basah yang dihasilkan pada petak kontrol merupakan bobot terendah dibandingkan perlakuan insektisida BPMC dan ekstrak daun suren. Sementara itu, pada petak perlakuan insektisida BPMC dan ekstrak daun suren, kehilangan hasil produksi padi dapat dicegah karena terdapat pengendalian aplikasi insektisida sehingga populasi WBC dapat dikendalikan.

Tingkat efikasi setelah aplikasi ekstrak pada umur 49 HST pada perlakuan ekstrak daun suren 50 g/l yaitu 100\% (Tabel 2). Berdasarkan tingkat efikasi insektisida ekstrak daun suren dapat dijadikan alternatif insektisida nabati untuk mengurangi penggunaan insektisida sintetis. Tingkat efikasi $100 \%$ terdapat pada perlakuan insektisida ekstrak daun suren 50 g/l, 150 g/l dan insektisida BPMC 1,5 $\mathrm{ml} / \mathrm{l}$. Tingkat efikasi insektisida dipengaruhi oleh tinggi atau rendahnya konsentrasi dalam penggunaan insektisida (Adnyana dkk., 2012).

Tabel 2. Tingkat efikasi insektisida BPMC dan ekstrak daun suren terhadap WBC.

\begin{tabular}{lc}
\hline \multicolumn{1}{c}{ Perlakuan } & Tingkat Efikasi (\%) \\
\hline Ekstrak daun suren $50 \mathrm{~g} / \mathrm{l}$ & 100 \\
Ekstrak daun suren $100 \mathrm{~g} / 1$ & 88,89 \\
Ekstrak daun suren $150 \mathrm{~g} / 1$ & 100 \\
Insektisida BPMC 0,5 ml/1 & 88,89 \\
Insektisida BPMC $1,0 \mathrm{ml} / 1$ & 77,78 \\
Insektisida BPMC $1,5 \mathrm{ml} / 1$ & 100 \\
\hline
\end{tabular}

\section{SIMPULAN}

Insektisida BPMC dan ekstrak daun suren dapat menekan hama WBC dan berpengaruh terhadap hasil produksi padi varietas Ciherang. Perlakuan ekstrak daun suren $50 \mathrm{~g} / \mathrm{l}$ dapat menekan hama WBC karena setelah aplikasi ketiga tidak ditemukan populasi WBC. Perlakuan insektisida BPMC 1,5 ml/1 menghasilkan produksi bobot basah gabah tertinggi dengan rata-rata produksi 37,80 $\mathrm{kg}$ /petak dibandingkan dengan pada perlakuan kontrol yang merupakan produksi bobot basah gabah terendah yaitu $32,63 \mathrm{~kg} /$ petak.

\section{DAFTAR PUSTAKA}

Adnyana, IG Silla, K Sumiartha, dan IP Sudiarta. 2012. Efikasi pestisida nabati minyak atsiri tanaman tropis terhadap mortalitas ulat bulu gempinis. Agroekoteknologi Tropika. 1:2301-6515.

Baehaki, SE, K Arifin, dan D Munawar. 2011. Peran varietas tahan dalam menurunkan populasi wereng coklat Biotipe 4 pada tanaman padi. Penelitian Pertanian Tanaman Pangan. 30 (3):145-153.

BBPOPT-Ditjen PPT. 1992. Wereng Batang Coklat. Balai Besar Penelitian Oraganisme 
Pengganggu Tumbuhan dan Direktoral Jendral Pertanian Tanaman Pangan. Laporan Akhir.

Caraycaray, MDB. 2004. More farmers use innovative chemical-free methods to control pest in rice. Phil. Rice Newsletter. 16(4):187-194.

Chakraborty, K, MN Moitra, AK Sanyal, and PC Rath. 2016. Important natural enemy of paddy insect pest in the upper gangetic plains of West Bengal India. International Journal of Plant, Animal and Environmental Sciences. 6(1):35-40.

Hadi, UK. 2012. Fenomena Tomcat atau Dermatitis paederus. Tersedia online pada: http://upikke.

staff.ipb.ac.id/files/2012/03/FenomenaDerm atitis-Paederus-tomcat.1). (diakses 20 Juli 2015).

Hidayati, NN, Yuliani, dan N Kuswanti. 2013. Pengaruh ekstrak daun suren dan daun mahoni terhadap mortalitas dan aktivitas makan ulat daun (Plutella xylostella) pada tanaman kubis. LenteraBio. 2(1):95-99.

IRAC. 2012. Brown planthopper Nilaparvata lugens. Insecticide Resistance Action Committee News Letter. Tersedia online pada: http://www.irac-

online.org/pests/nilaparvata-lugens. (diakses 18 Juli 2015).

Luo, Y, H Fu, and S Traore. 2014. Biodiversity conservation in rice paddies in China: Toward ecological sustainability. Sustainability. 6(2):6107-6124.

Muddasir, M, Z Ahmad, MJ Fardusi, and A Rehman. 2015. Effects of biological insecticides on predatory spider's population in rice field. International Journal of Innovation and Applied Studies. 11(1):114-117.

Nagata, T. 1985. Chemical control of the brown planthopper in Japan. JARQ. 18(3):176-181.
Noviana, E. 2011. Uji potensi ekstrak daun suren (Toona sureni Blume) sebagai insektisida ulat grayak (Spodoptera litura. F) pada tanaman kedelai (Gycine max L.). Universitas Sebelas Maret. Surakarta.

Nurbaeti, B, IGP Alit Diratmaja, dan S Putra. 2010. Hama Wereng Coklat (Nilaparvata lugens Stal.) dan Pengendaliannya. Balai Pengkajian Teknologi Pertanian Jawa Barat.

Rizkie, L, S Herlinda, dan Suparman. 2015. Serangga Hama dan Arthropoda Predator yang Terdapat pada Padi Lebak di Desa Pelabuhan Dalam Kecamatan Pemuluatan Provinsi Sumatera Selatan. Prosiding Seminar Nasional Lahan Suboptimal 2015, Palembang 8-9 Oktober 2015.

Santosa, SJ dan J Sulistyo. 2007. Peranan musuh alami hama utama padi pada ekosistem sawah. Jurnal Inovasi Pertanian. 6(1):1-10.

Sjakoer, N. 2010. Mortalitas hama Wereng Punggung Putih setelah dimangsa oleh serangga predator (pengamatan visualisasi di green house). Jurnal El-Hayah. 1(2):35-39.

Sutrisno. 2014. Resistensi wereng batang cokelat padi, Nilaparvata lugens Stål terhadap insektisida di Indonesia. Jurnal AgroBiogen. 10(3):115-124.

Syahrawati, M Busniah, dan N Nelly. 2010. Sosialisasi Teknik Konservasi Musuh Alami Wereng Coklat (Nilaparvata lugens) pada Petani Perempuan. Lembaga Pengabdian kepada Masyarakat Universitas Andalas. Padang.

Wispriyono, B, A Yanuar, dan L Fitria. 2013. Tingkat keamanan konsumsi residu karbamat dalam buah dan sayur menurut analisis pascakolom kromatografi cair kinerja tinggi. Jurnal Kesehatan Masyarakat Nasional. 7(7):317-323. 